Research article

urn:1sid:zoobank.org:pub:DFEFCFAA-D2FF-4B9E-8EF5-2E4B895D25F5

\title{
New species of Boreohesperus (Diplopoda, Polydesmida, Paradoxosomatidae) from north-western Australia
}

\author{
Catherine A. CAR ${ }^{1, *} \&$ Mark S. HARVEY ${ }^{2,3,4,5}$ \\ ${ }^{1,2}$ Department of Terrestrial Zoology, Western Australian Museum, Locked Bag 49, \\ Welshpool DC, Western Australia 6986, Australia. \\ ${ }^{3}$ Research Associate, Division of Invertebrate Zoology, American Museum of Natural History, \\ Central Park West at 79th Street New York, NY 10024, USA. \\ ${ }^{4}$ Research Associate, Department of Entomology, California Academy of Sciences, \\ 55 Music Concourse Drive, San Francisco, CA 94118 USA. \\ ${ }^{5}$ Adjunct, School of Animal Biology, University of Western Australia, 35 Stirling Highway, \\ Crawley, Western Australia 6009, Australia. \\ ${ }^{*}$ Corresponding author: catherine.car@museum.wa.gov.au \\ ${ }^{2}$ Email: mark.harvey@museum.wa.gov.au \\ ${ }^{1}$ urn:Isid:zoobank.org:author:8C425D2C-EF55-4DCC-A3E6-E4901E6A4A99 \\ ${ }^{2}$ urn:lsid:zoobank.org:author:FF5EBAF3-86E8-4B99-BE2E-A61E44AAEC2C
}

\begin{abstract}
To date, six species of the Australian endemic millipede genus Boreohesperus have been recognized: all have highly localized distributions, consistent with being short-range endemic species, and all are from the Cape Range and Pilbara region of Western Australia. In this paper, we describe three new species, B. alcyonis sp. nov., B. psittacinus sp. nov., and B. vascellus sp. nov., each from a different island in the Kimberley region of north-western Australia.
\end{abstract}

Keywords. Taxonomy, morphology, short-range endemism, millipede, gonopod.

Car C.A. \& Harvey M.S. 2017. New species of Boreohesperus (Diplopoda, Polydesmida, Paradoxosomatidae) from north-western Australia. European Journal of Taxonomy 320: 1-11. https://doi.org/10.5852/ejt.2017.320

\section{Introduction}

The keeled millipede genus Boreohesperus Shear, 1992 was reviewed recently (Car \& Harvey 2013) and six species were recognised, all from north-western Australia. In that earlier paper, the nomenclature of the branches of the male gonopods was revised because it is the male gonopod that is used almost exclusively for distinguishing between paradoxosomatid species (Brölemann 1913; Jeekel 1982; Eberhard 1993). Car \& Harvey (2013) stated that a "separate process arising from the base of the gonopod in some species is tagged the "pp"". This should read "a separate process arising from the base of the solenomere (bs) is tagged the posterior process (pp)". After the publication of Car \& Harvey (2013) several additional specimens of Boreohesperus were located in the collection of the Western Australian Museum, representing three new species, described in this paper. These new species conform to the 
general diagnosis of Boreohesperus recently presented by Car \& Harvey (2013), but their gonopods show enough variation to warrant a redescription of the genus to accommodate them.

Each of these new species is found on a separate island, all approximately $140 \mathrm{~km}$ north of Derby in the Kimberley region of Western Australia. These discoveries substantially extend the range of the genus, as all other species are found in the Cape Range and Pilbara regions, approximately $600-1200 \mathrm{~km}$ southwest of the new species. No other species of the genus have been collected in the intermediate area to date.

\section{Material and methods}

All of the specimens examined for this study are preserved in $75 \%$ ethanol, and are lodged in the Western Australian Museum, Perth (WAM).

The specimens were examined with Leica MZ6 and MZ16A stereo microscopes and the images were generated with a Leica MZ16A automontage imaging system using Leica Application Suite Version 3.7.0 software. Images of whole specimens and their dorsal views were captured first. The left gonopod from each specimen was then removed and a set of images of the gonopod with four different orientations (posterior, anterior, medial and lateral) was captured. Descriptions were compiled with the software package DELTA (Dallwitz 1999) and the map was generated with ArcGIS version 10.1.

Site references (site ref.) referred to in the specimen information sections are field codes assigned to the specimens by collectors representing environmental consultancy firms. They are included for completeness.

Abbreviations and terms used in gonopod labelling follow that of Car \& Harvey (2013).

\section{Results}

Order Polydesmida Pocock, 1887

Suborder Strongylosomatidea Brölemann, 1916

Family Paradoxosomatidae Daday, 1889

Subfamily Australiosomatinae Brölemann, 1916

Tribe Australiosomatini Brölemann, 1916

Genus Boreohesperus Shear, 1992

Fig. 1

Boreohesperus Shear, 1992: 778.

\section{Type species}

Boreohesperus capensis Shear, 1992, by original designation.

\section{Diagnosis}

Boreohesperus may be distinguished from the four other genera of Australian paradoxosomatids whose gonopods divide into two main branches, Dicladosoma Brölemann, 1913, Dicladosomella Jeekel, 1982, Oncocladosoma Jeekel, 1985 and Somethus Chamberlin, 1920, by the two main branches of its gonopod arising from a distinct femorite that may vary from one-quarter to one-half of the acropodite length. In contrast, in Dicladosoma, the two thick gonopod branches arise from the prefemur, and the gonopods of each of the other three genera are split into two main branches much more deeply than in Boreohesperus, almost to the base of the acropodite. 


\section{Description}

The type species description remains unchanged from that set out in the first paper on Boreohesperus by Car \& Harvey (2013).

\section{Taxonomic notes}

The new species are considerably larger than those previously described, except $B$. capensis, ranging in length from approximately $16-20 \mathrm{~mm}$. They, like $B$. capensis, also lack paranota. The gonopods

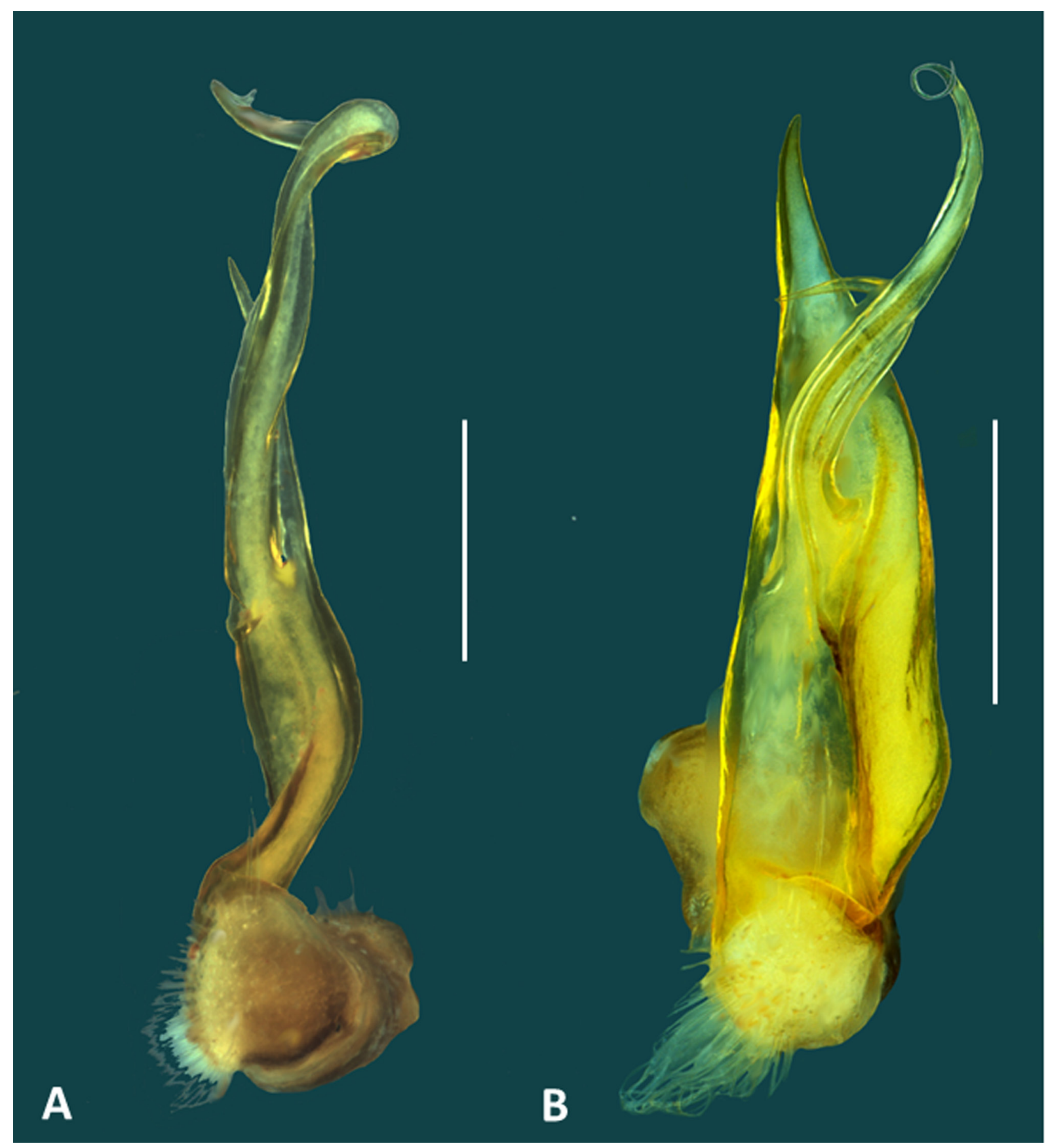

Fig. 1. Posterior view of left gonopod of Boreohesperus spp. A. Boreohesperus capensis Shear, 1992. B. B. vascellus sp. nov. Scale bars: $0.5 \mathrm{~mm}$. 
of the three new species are also relatively larger ( $>1 \mathrm{~mm}$ in length) and much more robust than the delicate structures of the other species, five of which have gonopods less than $1 \mathrm{~mm}$ in length. In all three new species, the gonopod femorite is relatively longer (approximately one-half the acropodite length), stockier and extremely broad when compared with those of the southern species, particularly that of the type species. It seems that the new Koolan Island species (B. vascellus sp. nov.) represents one extreme of femorite stoutness while B. capensis has the most slender femorite of all (Fig. 1). Finally, with the exception of $B$. capensis, each of the described southern species has a marked bifurcation of the solenomere tip: two of the new species carry a small process at the solenomere tip; in the third, a process is entirely lacking.

\section{Boreohesperus alcyonis sp. nov. urn:1sid:zoobank.org:act:0D2CB02B-91F7-4C02-903B-FC4C7B9D8530}

Figs 2, 5

\section{Diagnosis}

This species is readily distinguished from those previously described by its large, robust gonopod with a long, broad femorite. It differs from Boreohesperus psittacinus sp. nov. and B. vascellus sp. nov. in its long, curled solenomere on the gonopod which lacks a tip process: this process is present in the other two species. B. alcyonis sp. nov. also has a distinctive long, slender non-seminiferous branch process on the gonopod that curves to the solenomere tip.

\section{Etymology}

This species is named for the island on which it was found, Kingfisher Island (from the Latin 'alcyon, -is', noun, kingfisher).

\section{Type material}

\section{Holotype}

WESTERN AUSTRALIA: ${ }^{\lambda}$, Kingfisher Island, $16^{\circ} 04^{\prime} 55^{\prime \prime}$ S, $124^{\circ} 04^{\prime} 15^{\prime \prime}$ E, Biota site ref. D20100209 KIS3-171-1, vine thicket, 9 Feb. 2010, R. Teale leg. (WAM T108780).

\section{Paratypes}

WESTERN AUSTRALIA: $2 \precsim \hat{\jmath}$, same data as holotype (WAM T140186).

\section{Description}

\section{Male (holotype)}

Body approximately $16 \mathrm{~mm}$ long; mid-body approximately $2 \mathrm{~mm}$ wide dorsally with distinct waist between prozonite and metazonite; legs of moderate length, approximately equal to length of 1-2 midbody rings. Colour uniform chestnut brown. Paranota absent. Sternites, other than those of the fifth body ring, with no noticeable features. Sternal lamella broad, square and short, reaching just above the coxae of the second pair of legs on body ring 5. Anterior spiracles at mid-body elliptical, small, facing slightly posteriorly. Antennae not obviously clavate, fifth and sixth antennomeres only slightly wider than proximal ones, short, not extending to body ring 2, antennomeres relatively slender (Fig. 2A). Gonopod (Fig. 2C-F) extending to posterior edge of fifth body ring; coxa (C) robust and approximately $2 \times$ as long as broad; prefemur (PF) short, sub-triangular; femorite $(\mathrm{F})$ half the length of acropodite, slightly narrower at base, then broadening noticeably; non-seminiferous branch (NSB) extending almost to solenomere tip as an upright, broad, pointed process; process on medial surface of NSB (nsbp) long and very slender, arising approximately midway on the length of the NSB and curving upwards almost to the solenomere tip ; solenomere (S) relatively long and slender, arising midway between NSB tip and $\mathrm{PF}$, basal third curving away from NSB and tip curling back towards gonopod midline to form a slender 
loop; solenomere tip undivided with no process; solenomere process ( $\mathrm{sp}$ ) absent; separate posterior process (pp) arising near solenomere base, long, slender, pointed and at least half solenomere length.

\section{Female}

Unknown.

\section{Distribution}

This species is known from three males only, collected from Kingfisher Island.
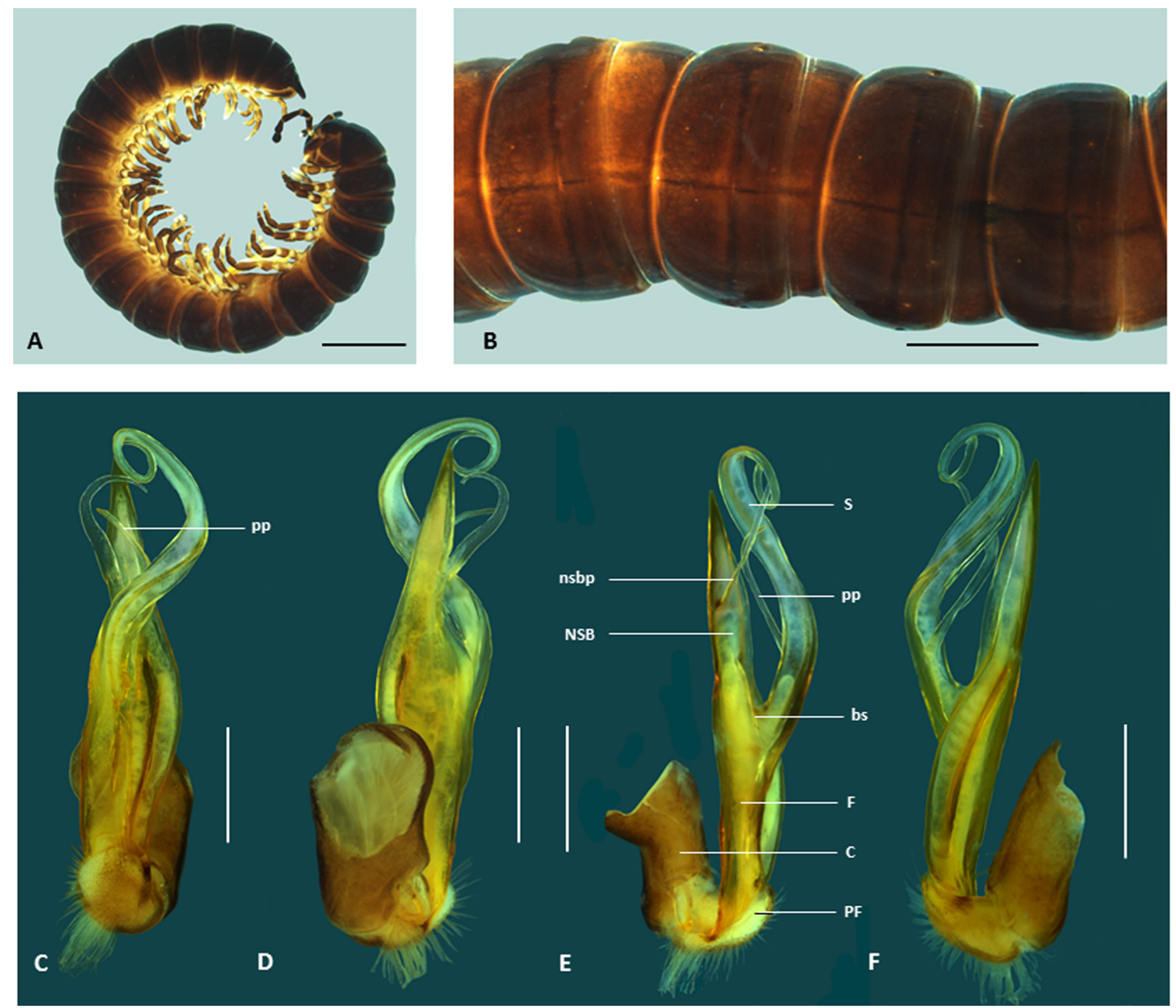

Fig. 2. Boreohesperus alcyonis sp. nov., holotype, ${ }^{\lambda}$ (WAM T108780). A. Habitus, lateral view. B. Habitus, dorsal view. C-F. Left gonopod. C. Posterior view. D. Anterior view. E. Medial view. F. Lateral view. Abbreviations: $\mathrm{bs}=$ solenomere base; $\mathrm{C}=$ coxa; $\mathrm{F}=$ femorite; $\mathrm{NSB}=$ non-seminiferous branch; $\mathrm{nsbp}=$ non-seminiferous branch process; $\mathrm{PF}=$ prefemur; $\mathrm{pp}=$ posterior process; $\mathrm{S}=$ solenomere. Scale bars: $\mathrm{A}=2 \mathrm{~mm} ; \mathrm{B}=1 \mathrm{~mm} ; \mathrm{C}-\mathrm{F}=0.5 \mathrm{~mm}$. 


\section{Boreohesperus psittacinus sp. nov. \\ urn:1sid:zoobank.org:act:4E2A401B-20E9-4958-8E12-56C743E7F64F}

Figs 3,5

\section{Diagnosis}

This species can be easily separated from the southern described species because it is much larger and the male has a much more robust gonopod with a long broad femorite. It is readily distinguished from $B$. alcyonis sp. nov. by gonopodal characters: the presence of a small process at the solenomere tip and a short process on the non-seminiferous branch: these processes are absent in B. alcyonis sp. nov. The gonopodal femorite and non-seminiferous branch together form a smooth upright flame-shaped structure, gradually narrowing when viewed laterally: in contrast, the gonopodal femorite of B. vascellus sp. nov. is noticeably narrow at its base laterally and, again, the non-seminiferous branch is narrower at its base than at its midpoint.

\section{Etymology}

This species is named for the island on which it was found, Cockatoo Island (from the Latin 'psittacinus', of parrots).

\section{Type material}

\section{Holotype}

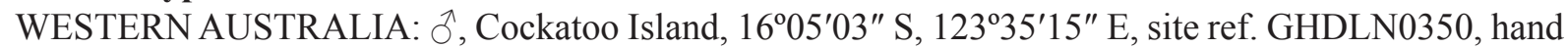
foraging, hummock grassland, 8 Feb. 2014, G. Owen leg. (WAM T132609).

\section{Paratypes}

WESTERN AUSTRALIA: $2 \hat{\jmath} \bar{\partial}$, details as for holotype, but site ref. GHDLN0342, 12 Feb. 2014 (WAM T132608).

\section{Other material examined}

WESTERN AUSTRALIA: 1 juvenile, details as for paratypes, but site ref. GHDLN0371 (WAM T132611); 1 ऽ, details as for paratypes, but site ref. GHDLN0394, 14 Feb. 2014 (WAM T132613); 1 ठ, details as for paratypes, but site ref. GHDLN0396, 14 Feb.2014 (WAM T132614); also from Cockatoo Island: 1 juvenile, $16^{\circ} 05^{\prime} 28^{\prime \prime} \mathrm{S}, 123^{\circ} 36^{\prime} 03^{\prime \prime} \mathrm{E}$, site ref. GHDLN0382, pitfall trap in eucalyptus woodland, 7-12 Feb. 2014, G. Owen leg. (WAM T132612).

\section{Description}

Male (holotype)

Body approximately $20 \mathrm{~mm}$ long; mid-body approximately $1.5 \mathrm{~mm}$ wide dorsally with distinct waist between prozonite and metazonite; legs of moderate length, approximately equal to length of 1-2 midbody rings. Colour uniform dark brown. Paranota absent. Sternites, other than those of the fifth body ring, with no noticeable features. Sternal lamella, broad and square, anterior edge with a slightly raised mid-point, extending to the posterior edge of ring 4. Anterior spiracles at mid-body small, flat ovoid. Antennae not obviously clavate, sixth antennomere only slightly wider than proximal ones, short, not extending to body ring 2, antennomeres moderately slender (Fig. 3A). Gonopod (Fig. 3C-D, F) extending to posterior edge of fifth body ring; coxa (C) robust and approximately $2 \times$ as long as broad; prefemur (PF) short, sub-globose; femorite (F) half the length of acropodite, slightly narrower at base, then broadening noticeably; non-seminiferous branch (NSB) extending almost to solenomere tip as an upright, broad, flame-shaped process; process on medial surface of NSB (nsbp) short and pointed, arising approximately midway on the length of the NSB; solenomere (S) relatively long and slender, arising midway between NSB tip and prefemur, basal third curving away from NSB and tip curling back 
towards gonopod midline to form an arc; solenomere tip with small process (stp); solenomere process (sp) absent; separate posterior process (pp) arising near solenomere base, long, slender, pointed and at least half solenomere length.

\section{Female}

Unknown.

\section{Distribution}

This species is known from only a few individuals collected in grassland on Cockatoo Island.
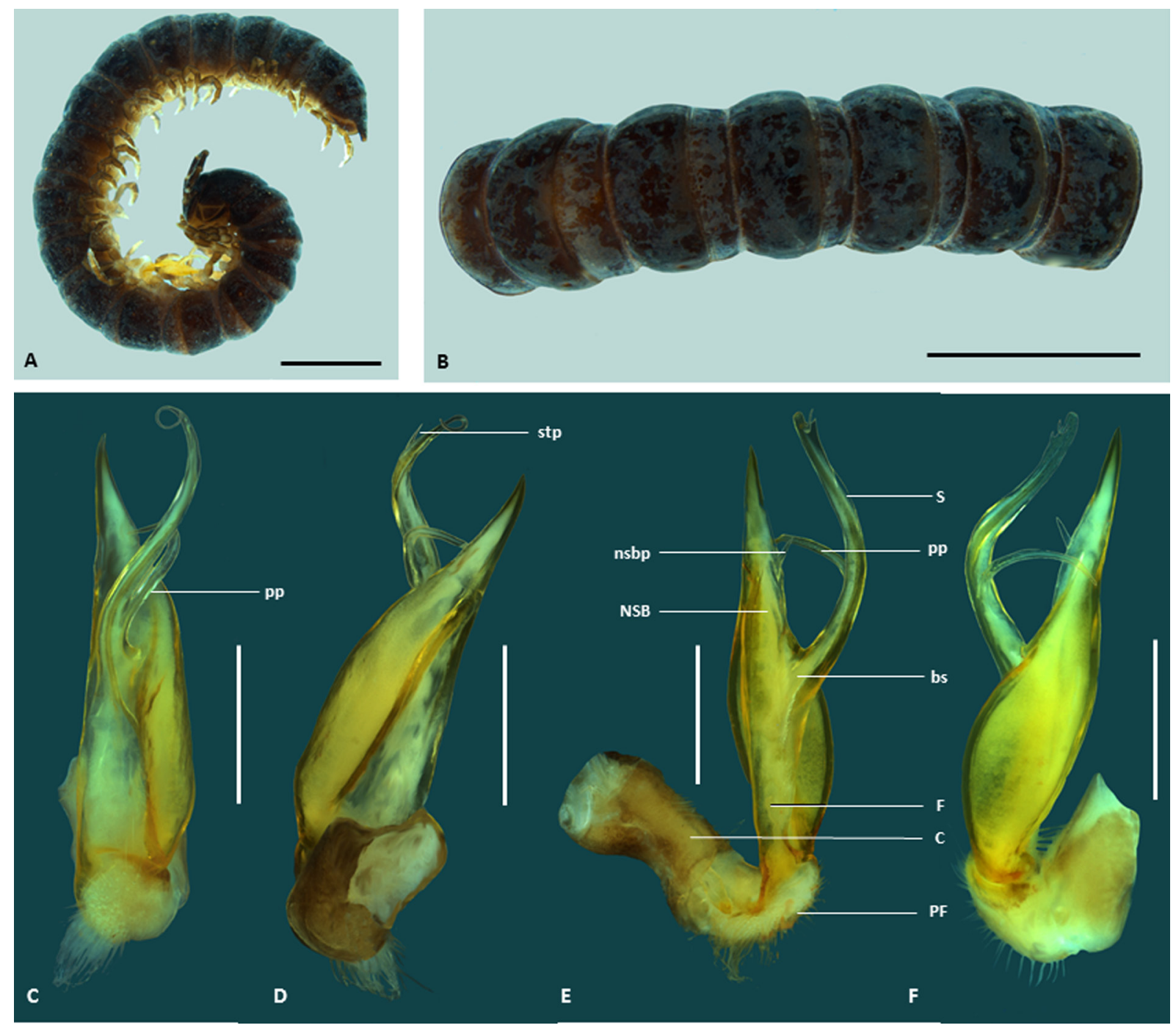

Fig. 3. Boreohesperus psittacinus sp. nov. A. Holotype, §, habitus (WAM T132609). B. Paratype, ðૈ, habitus (WAM T132608). A. Lateral view. B. Dorsal view. C-D, F. holotype, ô, left gonopod. E. Paratype, $\widehat{\jmath}$, left gonopod. C. Posterior view. D. Anterior view. E. Medial view. F. Lateral view. Abbreviations: $\mathrm{bs}=$ solenomere base $\mathrm{C}=\operatorname{coxa} ; \mathrm{F}=$ femorite $\mathrm{NSB}=$ non-seminiferous branch; $\mathrm{nsbp}=$ non-seminiferous branch process; $\mathrm{PF}=$ prefemur; $\mathrm{pp}=$ posterior process; $\mathrm{S}=$ solenomere; $\mathrm{stp}=$ solenomere tip process. Scale bars: $A=2 \mathrm{~mm} ; \mathrm{B}=1 \mathrm{~mm} ; \mathrm{C}-\mathrm{F}=0.5 \mathrm{~mm}$. 
Boreohesperus vascellus sp. nov.

urn:lsid:zoobank.org:act:75C21DCD-E403-4B9E-A72E-DFEA369EEED7

Figs $4-5$

\section{Diagnosis}

This species can be distinguished from all other species in the genus by combined features of the male gonopod: this has an extremely broad femorite, a distinctively shaped (flame-shaped, broadest at its mid-point) non-seminiferous branch and a relatively long, pointed curved posterior process.

\section{Etymology}

The gonopod of this species is reminiscent of a small vase (from the Latin 'vascellum', noun dim., vessel, vase).
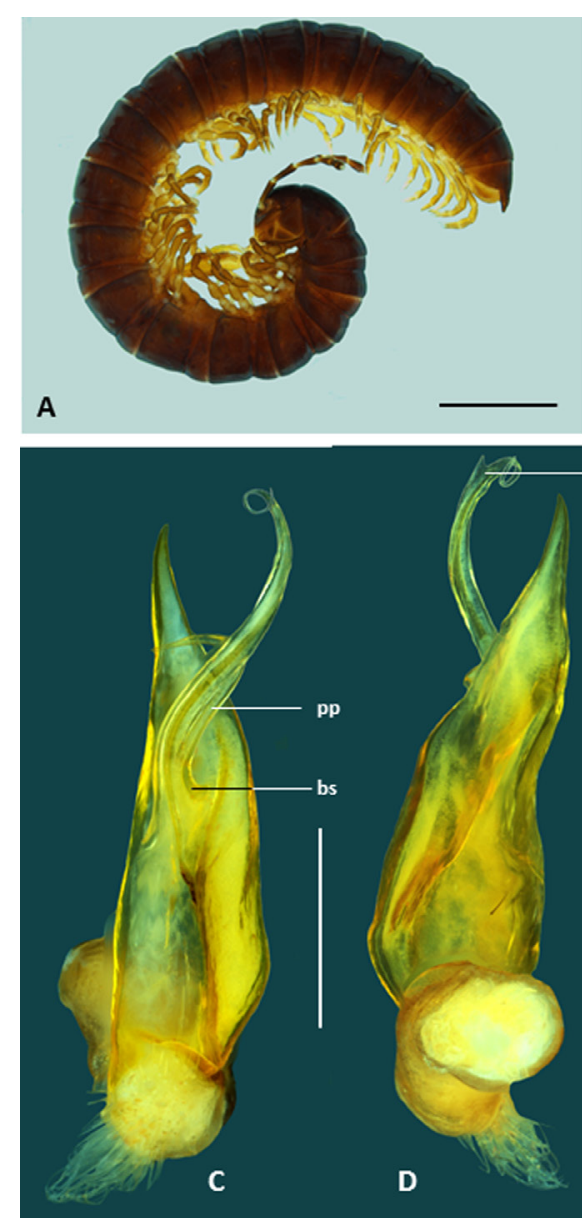
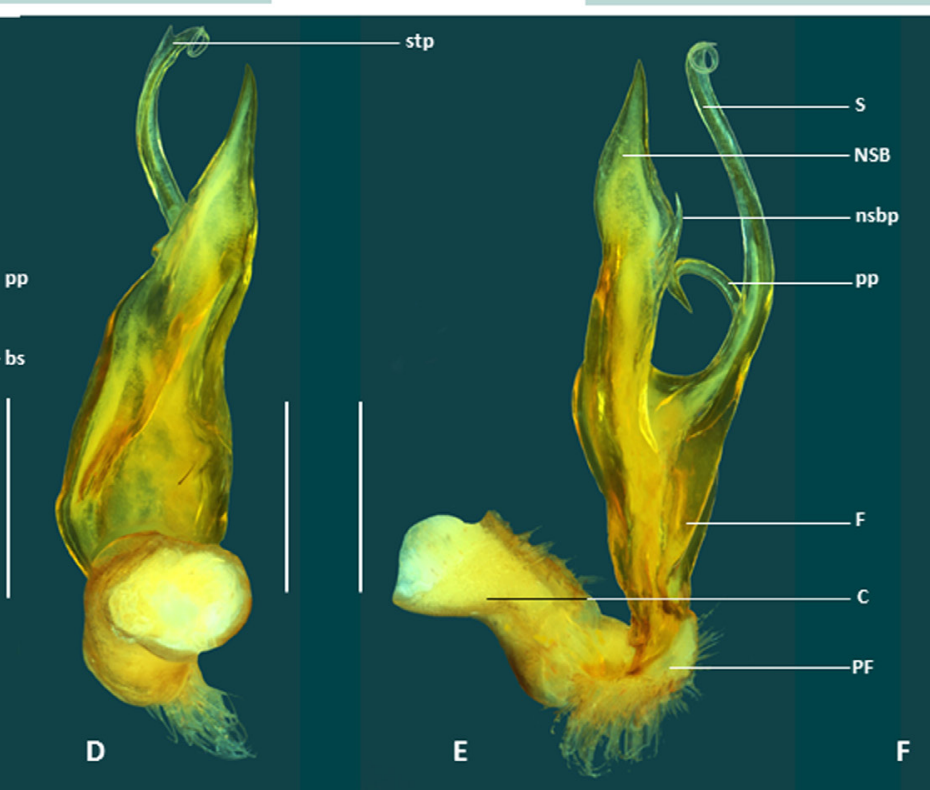

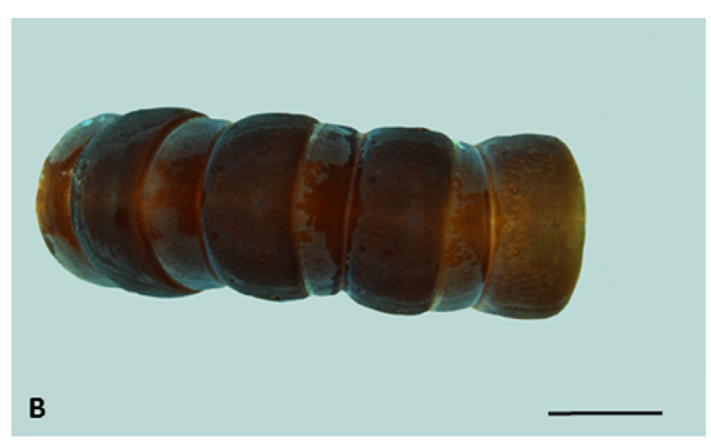

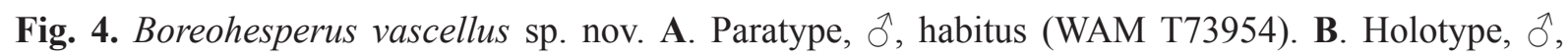
habitus (WAM T137095). A. Lateral view. B. Dorsal view. C, E-F. Paratype, ô, left gonopod (WAM T73954). D. Holotype, ô, left gonopod (WAM T137095). C. Posterior view. D. Anterior view. E. Medial view. F. Lateral view. Abbreviations: $\mathrm{bs}=$ solenomere base; $\mathrm{C}=$ coxa; $\mathrm{F}=$ femorite; $\mathrm{NSB}=$ nonseminiferous branch; $\mathrm{nsbp}=$ non-seminiferous branch process; $\mathrm{PF}=$ prefemur; $\mathrm{pp}=$ posterior process; $\mathrm{S}=$ solenomere; $\mathrm{stp}=$ solenomere tip process. Scale bars: $\mathrm{A}=2 \mathrm{~mm} ; \mathrm{B}=1 \mathrm{~mm} ; \mathrm{C}-\mathrm{F}=0.5 \mathrm{~mm}$. 


\section{Type material}

\section{Holotype}

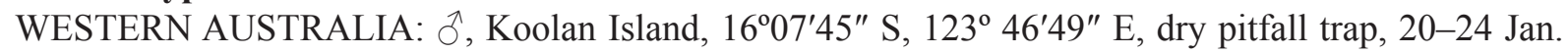
2006, B. Maryan leg. (WAM T137095).

\section{Paratypes}

WESTERN AUSTRALIA: $2 \widehat{\partial} \widehat{\partial}$, same data as for holotype (WAM T73954).

\section{Description}

Male (holotype)

Body approximately $18 \mathrm{~mm}$ long; mid-body approximately $1.5 \mathrm{~mm}$ wide dorsally with distinct waist between prozonite and metazonite; legs of moderate length, approximately equal to length of 1-2 mid-body rings. Colour uniform chestnut brown. Paranota absent. Sternites, other than those of the fifth body ring, with no noticeable features. Anterior spiracles at mid-body, very small, flat, ovoid, slightly posteriorly facing. Antennae not obviously clavate, sixth antennomere only slightly wider than proximal ones, short, not extending to body ring 2, antennomeres moderately slender (Fig 4A). Gonopod (Fig. 4D) extending to posterior edge of fifth body ring; coxa (C) robust and approximately $2 \times$ as long as broad; prefemur (PF) short, sub-globose; femorite (F) half the length of acropodite, narrow at base, then broadening considerably; non-seminiferous branch (NSB) extending almost to solenomere tip as an upright, very broad, process, narrowing abruptly to a pointed tip; process on medial surface of NSB (nsbp) very short and pointed, arising approximately midway on the length of the NSB; solenomere (S)

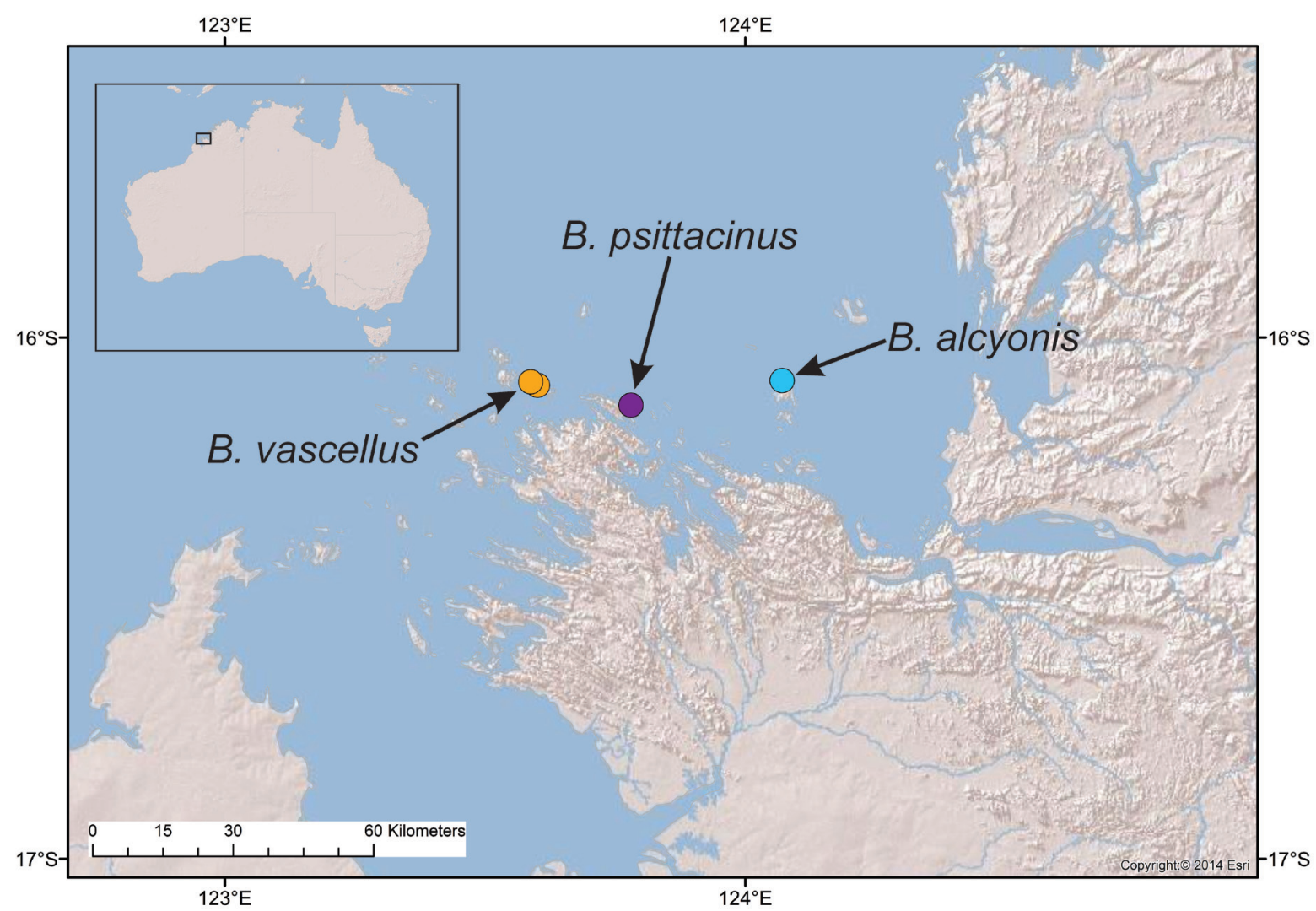

Fig. 5. Map of the Kimberley region of north-western Australia showing the distributions of the three new species of Boreohesperus Shear, 1992. 
relatively long and slender, arising midway between NSB tip and prefemur, curving away slightly from NSB and tip curling back towards gonopod midline to form a small loop; solenomere tip with small process (stp); solenomere process ( $\mathrm{sp}$ ) absent; separate posterior process (pp) arising near solenomere base, slender, pointed, curving away almost a right angles from the solenomere to abut against the NSB .

\section{Female}

Unknown.

\section{Distribution}

This species in known from only three males on Koolan Island (Fig. 5).

\section{Discussion}

Nine species of the millipede genus Boreohesperus have now been described, all in Western Australia (WA): six in the Pilbara and Cape Range regions and three on islands in the Kimberley region (Fig. 5). Two species from the Pilbara region, B. capensis and B. dubitalis Car \& Harvey, 2013 occur in the Cape Range area and on the offshore island of Barrow, respectively. These two localities are Tertiary limestone areas and were submerged in the Cretaceous period. In contrast, the Pilbara mainland, location of four species, is made up of Archaean cratonic crust (McKenzie et al. 2009). The three Kimberley islands have a very different history: they are all part of the Yampi Formation, which was initially laid down ca 1,800-1,840 Ma. It comprises various sandstone, siltstone and conglomerate units, and occasionally contains appreciable levels of hematite (Tyler \& Griffin 1992). The latter has been mined on Cockatoo and Koolan Islands. Suitable Boreohesperus habitats, namely grassland and vine thickets, are present on the mainland adjacent to the Kimberley Islands, and the lack of records for the mainland might simply be due to lack of surveys for litter invertebrates at suitable times of the year. The three Kimberley species were collected in January and February during the wet season, suggesting that males mature and emerge to search for females only when sufficient rain has occurred. The close proximity of the three island sites (separated by $20-30 \mathrm{~km}$, Fig. 5) indicates high species turnover, with each species most likely endemic to a single island. The possibility, then, that other islands in the Kimberley have other endemic species of Boreohesperus is quite high, and it seems probable too, that more mainland species exist. The collection of these species will depend on field surveys undertaken in appropriate weather conditions, especially during the high rainfall season.

\section{Acknowledgements}

Thanks go to Bill Humphreys for helpful discussions, and to Brad Maryan (Biologic), Gaynor Owen (GHD) and Roy Teale (Biota Environmental Sciences) for collecting the specimens.

\section{References}

Brölemann H.W. 1913. The Myriapoda in the Australian Museum. Part II. Diplopoda. Records of the Australian Museum 10: 77-158. https://doi.org/10.3853/j.0067-1975.10.1913.899

Car C.A. \& Harvey M.S. 2013. A review of the Western keeled millipede genus Boreohesperus (Diplopoda, Polydesmida, Paradoxosomatidae). ZooKeys 290: 1-19. https://doi.org/10.3897/zookeys.290.5114

Dallwitz M.J., Paine T.A. \& Zurcher E.J. 1999. User's guide to the DELTA Editor. Available from http:// delta-intkey.com [accessed 27 Apr. 2017].

Eberhard W. 1993. Evaluating models of sexual selection: genitalia as a test case. The American Naturalist 142 (3): 564-571. https://doi.org/10.1086/285556 
Jeekel C.A.W. 1982. Millipedes from Australia 1: Antichiropodini from South Australia (Diplopoda, Polydesmida, Paradoxosomatidae). Bulletin Zoölogisch Museum Universiteit van Amsterdam 8 (14): $121-132$.

Mckenzie N.L., Van Leeuwen S. \& Pinder A.M. 2009. Introduction to the Pilbara Biodiversity Survey, 2002-2007. Records of the Western Australian Museum, Supplement 78: 3-89. https://doi.org/10.18195/ issn.0313-122x.78(1).2009.003-089

Shear W.A. 1992. A new genus and two new species of millipedes from the Cape Range, Western Australia (Diplopoda, Polydesmida, Paradoxosomatidae). Records of the Western Australian Museum 15: 777-784.

Tyler I.M. \& Griffin T.J. 1992. Explanatory notes on the Yampi 1: 250000 geological sheet, Western Australia (2 ${ }^{\text {nd }}$ edition). Perth, Western Australia, Department of Mines.

Manuscript received: 26 May 2016

Manuscript accepted: 19 September 2016

Published on: 22 May 2017

Topic editor: Rudy Jocqué

Desk editor: Kristiaan Hoedemakers

Printed versions of all papers are also deposited in the libraries of the institutes that are members of the EJT consortium: Muséum national d'Histoire naturelle, Paris, France; Botanic Garden Meise, Belgium; Royal Museum for Central Africa, Tervuren, Belgium; Natural History Museum, London, United Kingdom; Royal Belgian Institute of Natural Sciences, Brussels, Belgium; Natural History Museum of Denmark, Copenhagen, Denmark; Naturalis Biodiversity Center, Leiden, the Netherlands; Museo Nacional de Ciencias Naturales-CSIC, Madrid, Spain. 